\title{
Scale Development to Measure Employer Engagement
}

\author{
Samina Khan ${ }^{a}$, Ulfat Abbas ${ }^{b}$, Rao Arif Mahmood Khan ${ }^{c^{*}}$ Muhammad \\ Irfan Sheikh $^{\mathrm{d}}$, , Hanzla Ahmed ${ }^{\mathrm{e}}$, Muhammad Masood Hussain ${ }^{\mathrm{f}}$, Hafiz

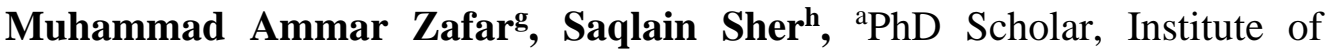

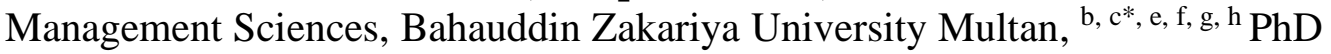 \\ Scholar, Institute of Business Management \& Administrative Sciences, The \\ Islamia University Bahawalpur, ${ }^{\mathrm{d}}$ Zonal Manager at AFAQ (Association For \\ Academic Quality), Email: ${ }^{a}$ khansamina44@yahoo.com,

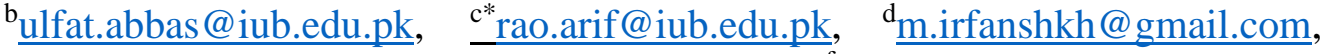 \\ ech.hanzla@gmail.com, $\quad{ }^{\mathrm{f}}$ masood007143@yahoo.com, \\ ghafizammarzafar@gmail.com, ${ }_{\text {saqlainsher@hotmail.com }}^{\text {shat }}$
}

\begin{abstract}
Employer engagement, in existing literature, mostly refers to the engagement of the educational institutions in the corporate world; to benchmark their curricula and syllabi in-line with the employers' needs. This study has focused on the same construct with different relation; typically in the context of work-based learning providers and organizational practices. Although there has been theoretical discussions and calls to develop comprehensive measures for employer engagement, however, no contemporary measure for employer engagement exist to the context this study was carried out. The scope of this study covers the development of a new scale based on the guidelines to measure employer engagement specifically to the context of work based practices. The scale constitutes of 19 items that address, employer engagement based on 3 sub-dimensions. The scale was developed and validated through six phases beginning with the determination of valid dimensions / construct followed by generation of pool of items, assessing the content adequacy of the items and items refinement through exploratory and confirmatory factor analysis. Reliability and validity of the scale are also tested.
\end{abstract}

Key words: Employer Engagement, Scale Development, Measurement Scale, Analytic 


\section{Introduction}

Engagement is a positive, two-way, relationship between the employees and their organization (Chiumento, 2004). Both parties understand the need of one another, and mostly know how to support and assist to fulfill the needs of each other accordingly (Armstrong, 2006). They perceive it mutually beneficial and invest resources in their relation, therefore, the engaged employees and organizations may go extra miles for each other (Chiumento, 2004).

Employee engagement is a construct that has widely been studied in the HR domain. Ample research has been conducted to measure employee engagement. Employer Engagement, is a relatively new concept. Less work has been carried out on employer engagement and going through different studies (John, 2014) it is revealed that it is not possible to arrive at a single shared definition of employer engagement (O'Donoghue, 2014). The use of this term is generally restricted to policy discourse (Hughes, Macleod, \& Maria, 2005), but this infrequently examines the specific question of 'engagement with whom?' Individuals from different disciplines may perceive the meaning of employer engagement differently, depending upon their role and responsibility.

The fundamental difference emerges from roles, responsibilities and school of thought of various disciplines. Individuals from educational institutions understood it as being about increasing and improving their own engagement with employers (Hughes, Macleod, \& Maria, 2005). Similarly, (Common Wealth, 2013) name it as "Strategic Employer Engagement Model". Although theoretically, the concept of employer engagement might be applicable to a wider set of public policies and public issues (Berkel, Ingold, McGurk, Bredgaard, \& Boselie, 2015) yet the perspective of this concept is indifferent.

Employer engagement is one of the parts of millennium development goals. Organizations like ILO (International Labor Organization) highlights global challenges and issues from time to time. Employer Engagement is one of those issues that is addressed at the global level. In response to the global issues and to cater millennium development goals; local governments and organizations develop their policies in line with those goals. Organizations strive hard to develop their policies, procedures and systems. The objective is to meet national policies, global challenges and to cope up with rivalry. Tan, et al., (2011) refers this to organizational innovation. In the race of obtaining competitive advantage and to become market leaders, human resource practices has been in the agenda of the organizations.

Since, very little research has been carried out to examine the engagement at the organizational level of analysis (Harter, Schmidt, \& Hayes, 2002). The little research has inclined to be excessively naive in its conceptualization and operationalization of organizational-level engagement (Barrick, Thurgood, Smith, \& Courtright, 2015). In this stance, the role of employer engagement, its antecedents and the mechanism that how organizational practices 
are linked to firm practices has not been addressed (Barrick, Thurgood, Smith, \& Courtright, 2015). This gap in knowledge leads to less understanding or few little judgments to conceptualize employer engagement; as it is still a relatively new concept in the management research literature (Rich, 2010). This lack of research on engagement regarding organizational level capabilities need exploration because it gives less information and knowledge about firms to achieve and sustain a high level of employer engagement. The objective of the study is twofold:

1. To determine the sub-dimensions that could cover the scope of the construct "Employer Engagement".

2. To develop a valid and reliable scale that could measure employer engagement at the organizational level, particularly in work based learning providers (Corporate Businesses).

This study contributes theoretically and empirically. Considering the studies of (Lepak, et al., 1999; Harter, et al., 2002; Barrick, et al., 2015; O’Donoghue, 2014 \& John, 2014) and the scope covered in defining the engagement of employers (Barber, et al., 2004 \& Rich, 2010); the study contributes in defining the naïve concept of what is employer engagement in corporate businesses? The earlier employer engagement was detailed with respect to the educational institutions and their engagement with the corporate world that only encompasses the selection of syllabi and curricula. This study expands the literature on how employer engagement could be used at the organizational level in the corporate businesses. Further, the study contributes in determining the dimensionality of the construct that covers the overall definition and scope of employer engagement at the organizational level. Moreover, the development of a valid and reliable scale that could measure Employer Engagement is another contribution of this study.

\section{Literature Review}

Employer engagement has been defined as "Active participation of employers in initiatives to promote the employability and labor market participation of the unemployed" (McGurk, 2014). It may be also be understood as, "A range of activities, initiatives and approaches which are best conceptualized as a continuum" (Web). A single, narrow definition of employer engagement might not encompass the full range of productive employer interactions with learning and might limit ambitions in extending useful work (O’Donoghue, 2014).

Scale development is an iterative, multi-method, qualitative, and quantitative process of item generation, refinement, evaluation, and selection (Alexandra \& Frank J., 2015). The principles of content validation guide all stages of scale development, which include construct definition, item content generation, item development and evaluation, and psychometric testing. Following the definition of the domain and the facets of each targeted construct, item content may be generated through population and expert sampling. Items and scale elements are 
evaluated and refined through the use of both expert review and psychometric evidence about item performance, internal consistency, factor structure, and multiple dimensions of validity (Alexandra \& Frank J., 2015).

As discussed above, there is less understanding of the term Employer Engagement pertaining to the internal organization working mechanisms and operations. It has found to be a naïve topic while going through different studies. Previous literature seemingly less verbal in discussing this construct, i.e., there is less literature available for Employer Engagement. However, below mention are the reviews of sub dimensions of the stated topic extracted from the literature. The 11 sub-dimensions of Employer Engagement that consolidates it are as follows:

\section{Pay \& Compensation}

Performance-based compensation is one of the dominant HR practices that firms use to evaluate and reward employees' efforts (Collins \& D., 2003). Compensation based on performance has a positive effect on employees as well as the organizations. It is evident from studies that the performance-based compensation has a positive effect upon employee and organizational performance (Cardon \& Stevens, 2004).

Barringer, et al., (2005) conducted a quantitative content analysis of 50 rapid-growth firms versus a group of 50 slow-growth firms and the results demonstrated that rapid-growth firms differentiated from the slow-growth firms respective to the employees' incentive policies. Performance based compensation and merit based promotion both are viewed as elements in organizational incentive systems that persuade and ensure individual performance and retention (Uen \& Chien, 2004).

\section{Training \& Development}

Training is the process of involving employees of the organization and improving their KSA (Knowledge, Skill and Abilities) to perform a specific task. Old and obsolete talents are updated using the trainings and new ones are developed accordingly. "Successful candidates placed on the jobs need training to perform their duties effectively" (Aswathappa, 2000). The prime concern and outcome of training is to provide skilled and willing workforce to the organization. In organizations, there are otherwise four distinct objectives lies at following levels like: Individual, Organizational, Functional, and Social (Kulkarni, 2013) proposed.

Skill development, knowledge development and education have a prominent and significant effect both on the short and long term indicators of organizational performance and personnel productivity and capacity building (Huselid, 1995). 


\section{Grievance Handling}

Dissatisfaction of employees with the working environment, procedures and working facilities, etc. In organizations, the grievances usually arouse because of unclear explicit rules and regulations lay down by the companies (Hook, Rollinson, Foot, \& Handley, 1996). Any stance or matter raised by employee to express dissatisfaction with management's behavior and an attempt to bring out changes (D'Cruz, 1999) in the organization as a result of any personal or collective arguments of the employees is called grievance. Another root cause of grievance of employees lies, according to (Ayadurai, 1996), is the disorders and uncertainty on provisions falling in the company's policy and the provisions' violation pertaining to terms and conditions of employment stated in collective agreement (Salamon, 2000). According to Meyer, (1994), an authentic grievance is a signal of erroneous behavior of the supervisor that has breach worker's right. Noe, et al., (2003) highlighted that too many grievances in the organization depict a severe problem while too few indicate a problem of another sort too.

\section{Employee Welfare \& Ergonomic}

Employee Welfare: International Labor Office (ILO) in its report defined Employees Welfare as, "Such services and amenities which may be established or in vicinity of undertakings to enable the persons employed in them to perform their work in healthy, congenial surroundings and provided with amenities conducive to good health and high morale" (Singla \& Goyal, 2015). Ergonomics means study of work. Ergonomics is treated under applied science phenomenon wherein it is dealt in designing the devices to be used at the workplace by the workers and working conditions of systems and physical environment conduciveness (Te-Hsin $\&$ Kleiner, 2001). There is a remarkable contribution of ergonomists in designing, planning and structuring the products, jobs and tasks in the industries (Kolgiri, Hiremath, \& Bansode, 2016).

\section{Job Security \& Performance}

Job security is tool that is used by HR practitioners to probe an environment of confidentiality among organization's employees. Practically, the company must pose a clear message for its employees that their jobs are secure. When employee starts feeling the same, their confidence and commitment towards the organizational success is increased. Those companies invest in ensuring job security that understands that securing employee's job will contribute to the company (Pfeffer, 1998). Perceived job security of full time employees was explored using psychological contract and social cognition theories. 


\section{Performance Appraisal}

Performance evaluations have been conducted since the times of Aristotle (Frank, Landy, Sheldon, Zedeck, \& Cleveland, 1983). The earliest formal employee performance evaluation program is thought to have originated in the United States military establishment shortly after the birth of the republic (Lopez, 1968).

The efficiency and effectiveness of performance appraisal exercise depends upon the ability to assess the performance of employees' in an accurate and fair manner. Christopher, et al., (2006) summarizes about including the present available information and the intrinsic motivational value as the necessary characteristic of the employees so as to get him involved in the performance appraisal process. Thurston, (2001) highlighted the specific characteristic related to performance appraisal and addressed the success and effectiveness of performance appraisal system. He said that employees' feedback is critical and important to the ensure successfulness and effectiveness of appraisal system. According to (Kinicki, Prussia, Bin, \& McKee-Ryan, 2004), richness of feedback elucidate particular appraisal environment wherein timely, specific and frequent feedback is given by employees to the organizations about their jobs.

\section{Recruitment \& Selection}

Recruitment is a process of identifying, attracting and seeking a pool of candidates out of which the suitable applicants can be selected by the organizations (Raymond, 2007). Recruitment is set of activities and practices exercised by the organizations with a primary objective and aim of attracting and identifying potential employees (Parry \& H, 2009). Organizations need to become successful for which they depend upon human capital; therefore, recruiting and selecting right personnel into the service business is essential for success (Zheng, 2009). Currently, in the process of recruitment and selection, organizations are trying to find out methods that should not take more effort and time (Vyas, 2011). The methods of recruitment and selection in the organizations should interpret to its competitive advantages (Munyon, Summers Ferris, \& Gerald, 2011).

\section{Diversity \& Equality}

Diversity management may be defined as the planned and systematic arrangement of recruiting, rewarding, promoting and retaining a heterogeneous mix of employees by the organization (Ongori \& Agolla, 2007). Diversity enhances effectiveness of the organization. Best personnel are attracted by the organizations who can best manage diversity and develop its experience in it (Carrell, Elbert, \& Hatfield, 2000). To meet challenges at global and domestic level, organizations are accepting and practicing a number of initiatives at their workplaces. 
It is understood by the organizations that managing diverse workforce effectively is essential to become successful. Simply having a diverse workforce is not necessary to get success. It is not mandatory for the organizations to enhance their performance mere by having increased diversity levels (Jayne \& Dipboye, 2004).

\section{Work Life Balance}

Work life balance is a broad concept; it has been defined in different research studies using different dimensions in different ways. Studying women in diverse roles leads to the origin of the research on this topic. Work life balance was initially termed as work family conflict by (Kahn, Wolfe, Quinn, Snoek, \& Rosenthal, 1964) and (Beutell \& Greenhaus, 1985) define it as "a form of inter role conflict in which the role pressures from work and family domains are mutually incompatible in some respect; i.e., participation in the work (family) role being made more difficult by virtue of participation in the family (work) role".

\section{Strategic Implementation}

Strategy researchers argue that firm's ability to create value leads to implementation of the strategic choices effectively (Child, 1972), (Cyert, 1963). According to resource management model, leaders usually combine available resources strategically to make capabilities and pull out the potential value contained within those resources (Sirmon, 2007). Hence, the capabilities are drawn out from structuring strategically, resource leveraging and bundling it up. According to (Child, 1972), the strategic choices theory claims that firms' leaders must have particularly defined strategic implementation objectives and they must be tracking the same along-with supreme monitoring. Any executive, team leader, strategic role player must play a vital role in not only formulating the organizational strategy but must be hands on with appropriate and effective implementation (Schendel, 1979).

\section{Corporate Social Responsibility}

Corporate Social Responsibility (CSR) was first defined by (Bowen, 1953) as the social obligation "to pursue those policies, to make those decisions, or to follow those lines of action which are desirable ion terms of the objectives and values of our society". Carroll, (1979) suggest CSR pyramid carrying four stages covering the heads like economic, legal, ethical and philanthropic obligations. Companies' reputation among the society in general and in the eyes of stakeholders is enhanced by using CSR as a strategic tool (McWilliams \& Seigel, 2010). Awareness about the CSR activities and programs of the firms should be made public by using any media facility (McWilliams \& Seigel, 2010). Corporate Social Responsibility has been defined under institutional theory. The institutional theory states that corporate social activities are not only voluntary activities, but it is a part of interface between business and society. 
International Journal of Innovation, Creativity and Change. www.ijicc.net

Volume 14, Issue 12, 2020

\section{Research Methodology}

The scale development, analysis and validation processes of Employer Engagement include six - 6 distinctive phases. These processes and phases are devised based on the work of (Churchill, 1979), (Hinkin, Tracey, \& Enz, 1997), (Hinkin T. , 1995) and (Shockley, Ureksoy, Rodopman, Poteat, \& Dullaghan, 2016).

\section{Phase - I (Determining the Valid Dimensions / Constructs):}

The first phase of the study includes the determination of the appropriate and valid construct (Churchill, 1979; Timothy, et al., 1997 \& Shockley, et al., 2016) that should cover the maximum scope of Employer Engagement. In order to ensure this, Phase - I was divided into two steps. The first one includes the review of the literature and detailed study of Employer Engagement referring different studies so as to identify the trend, scope, nature and phenomena of the topic. We propose that the dimensions of the employer engagement must cover all the sections of the (Social Ecological Model - SEM) model in the picture.

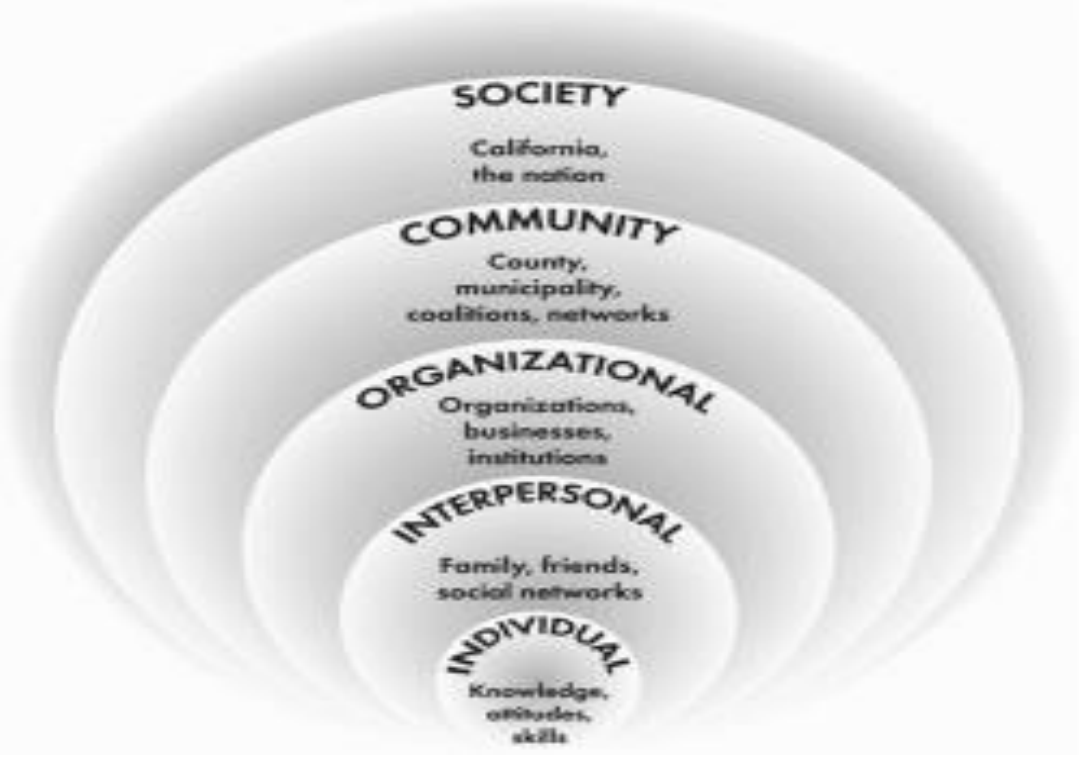

Figure 1: Social Ecological Model

\section{Phase - II (Generation of pool of items against each sub-dimension):}

In Phase - II, the process of generating pool of items (Hinkin, Tracey, \& Enz, 1997), (Churchill, 1979) and (Shockley, Ureksoy, Rodopman, Poteat, \& Dullaghan, 2016) was carried out. Objective was to create such items that must wrap, swathe and cover the entire scope of the topic. To ensure this, an approach was developed where items against each dimension of Employer Engagement identified in Phase - I should be generated. From different studies, it was revealed that item generation process could either be inductive or deductive (Hinkin, Tracey, \& Enz, 1997). Theoretical details and definitions of the construct are taken into account 
while using the deductive scale development process, which then may be used as a guide for the item generation process (Schwab, 1980). Hence, we've followed the deductive approach as this seems to be the most suitable one for this study.

Based on a number of studies and relevant measurement scales (Table - 2), different available items pertaining to each dimension are explored and included in the pool. The original scales are not used as such; however, the version is adapted with reference to the construct and nature of the data required.

Table 1: Measurement Scales Sources

\begin{tabular}{|c|l|c|l|}
\hline Sr. No & \multicolumn{1}{|c|}{ Sub-Dimension } & $\begin{array}{c}\text { In This } \\
\text { study }\end{array}$ & \multicolumn{1}{|c|}{ Reference } \\
\hline 1 & $\begin{array}{l}\text { Strategic Implementation\& } \\
\text { Welfare }\end{array}$ & Adapted & $\begin{array}{l}\text { (Barrick, Thurgood, Smith, \& } \\
\text { Courtright, 2015) }\end{array}$ \\
\hline 2 & $\begin{array}{l}\text { Corporate Social } \\
\text { Responsibility }\end{array}$ & Adapted & $\begin{array}{l}\text { (Tomina Gabriela, ABRUDAN, } \\
\text { GIURGIU, MESTER, \& } \\
\text { BUGNAR, 2014) }\end{array}$ \\
\hline 3 & Pay \& Compensation & Adapted & $\begin{array}{l}\text { (Jerez-Gómez, Céspedes-Lorente, } \\
\text { \& Valle-Cabrera, 2005) }\end{array}$ \\
\hline 4 & Appraisal & Adapted & $\begin{array}{l}\text { (Hayley, FORTIN, \& READ, } \\
\text { 2016) }\end{array}$ \\
\hline 5 & Ergonomics/Welfare/Safety & Adapted & $\begin{array}{l}\text { (Kenneth, MacDermid, Amick, \& } \\
\text { Beaton, 2011) }\end{array}$ \\
\hline 6 & Grievances Handing & Adapted & $\begin{array}{l}\text { (Zulkiflee, Yahya, Faizal, \& } \\
\text { Noor, 2011) }\end{array}$ \\
\hline 7 & Recruitment \& Selection & Adapted & (Quinn, 2014) \\
\hline 8 & Training \& Development & Adapted & (Bayissa, Asfaw, \& Argaw, 2015) \\
\hline 9 & Job Security / Performance & Adapted & (Bustillo \& Pedraza, 2005) \\
\hline 10 & Work Life Balance & Adapted & (Yung-Tai \& Chang, 2010) \\
\hline 11 & Diversity \& Equality & Adapted & (Northumbria, 2011) \\
\hline
\end{tabular}

We have collected a huge pool of 150 items (see Annex - II) against eleven dimensions of Employer Engagement in the initial pool generation exercise posing an average of around 14 questions per dimension.

\section{Phase - III (Content Adequacy Assessment):}

We have carried out the content adequacy assessment exercise twofold. First step was to identify the respondents, who, in this phase were the subject matter experts, again the same group as that of the Phase-I. The pool of 150 items collected against 11 dimensions of Employer Engagement was presented before the SMEs to have a review session for identifying redundancy, relevancy, categorization and sorting of the items accordingly. Out of 150 questions, 108 were left for further processing at the end of the step one. 
Subsequently, in the second step, experts were engaged to carry out the activity further. Pool of 108 items were presented to again validate the items according to the definitions of the dimensions, find out irrelevancies, identify redundancies and to gauge the suitability and placement of the items under each dimension. At the end of this exercise, we successfully approached to a final pool of 71 items with a pleasant feeling that the normal respondent in the market could get easier and trouble-free understanding of the matter and language of the items.

\section{Phase - IV (Questionnaire Administration)}

The items so retained from the previous exercise are then presented before the appropriate sample. The purpose of this work is to know how the selected items depict the desired results and expectations pertaining to the sub dimensions of Employer Engagement.

\section{Item Scaling}

For each of 71 items, 5-point Likert-type scale considering the level of likelihood and happening probability is used (Sorrel, 2010). It is the scale anchor that is most commonly used with questionnaires in research surveys (Schmitt \& Klimoski, 1991). The anchor defines five distinct choices each against a set number like:

Table 2: Likert Type Scale

\begin{tabular}{|c|c|c|c|c|}
\hline $\begin{array}{c}\text { Very Great } \\
\text { Extent }\end{array}$ & Great Extent & Some Extent & Little Extent & Very Little Extent \\
\hline 1 & 2 & 3 & 4 & 5 \\
\hline
\end{tabular}

\section{Participants:}

Before presenting the questionnaire to the population, it was decided that the participant should be a working paid employee of any organization. He/she must be at-least in middle or top management in the hierarchy of firm, must not be less than 18 years of age and preferably should hold confirm employment in any business organization of Pakistan.

\section{Reliability Test - Cronbach's Alpha}

Reliability refers to the consistency of the item-level errors within a single factor. Reliability means just what it sounds like: a "reliable" set of variables will consistently load on the same factor. The way to test reliability in an EFA is to compute Cronbach's alpha for each factor. The test shows the value of Cronbach's alpha as 0.972 for total number of items which is high enough from the minimum required and acceptable value of 0.7. However, (Churchill, 1979) stresses that the value of Cronbach's alpha should be on higher side to ensure the reliability. 
International Journal of Innovation, Creativity and Change. www.ijicc.net

Volume 14, Issue 12, 2020

\section{Exploratory Factor Analysis}

While developing a new scale there are two basic types of factor analyses that are used, the first one is termed as exploratory factor analysis (EFA) and the second one is known as confirmatory factor analysis (CFA). In this study both the methods are used. Table 3 the best solution as it depicts the cumulative variance \%age of 63.71 and with eigenvalue greater than 1 .

\begin{tabular}{|c|c|c|c|c|c|c|c|}
\hline \multicolumn{8}{|c|}{ Table 3: Three Factor Loadings Statistics } \\
\hline \multirow[t]{2}{*}{$\begin{array}{l}\text { Compone } \\
\text { nt }\end{array}$} & \multicolumn{3}{|c|}{ Initial Eigenvalues } & \multicolumn{3}{|c|}{$\begin{array}{c}\text { Extraction Sums of Squared } \\
\text { Loadings }\end{array}$} & \multirow{2}{*}{$\begin{array}{c}\text { Rotatio } \\
\text { n Sums } \\
\text { of } \\
\text { Square } \\
\text { d } \\
\text { Loading } \\
\mathbf{s}^{\mathbf{a}} \\
\text { Total }\end{array}$} \\
\hline & $\begin{array}{c}\text { Tot } \\
\text { al }\end{array}$ & $\begin{array}{c}\% \text { of } \\
\text { Varian } \\
\text { ce }\end{array}$ & $\begin{array}{l}\text { Cumulati } \\
\text { ve } \%\end{array}$ & $\begin{array}{c}\text { Tot } \\
\text { al }\end{array}$ & $\begin{array}{c}\% \text { of } \\
\text { Varian } \\
\text { ce }\end{array}$ & $\begin{array}{l}\text { Cumulati } \\
\text { ve } \%\end{array}$ & \\
\hline 1 & $\begin{array}{c}8.40 \\
5\end{array}$ & 44.239 & 44.239 & $\begin{array}{c}8.40 \\
5\end{array}$ & 44.239 & 44.239 & 6.808 \\
\hline 2 & $\begin{array}{c}2.17 \\
8\end{array}$ & 11.462 & 55.700 & $\begin{array}{c}2.17 \\
8\end{array}$ & 11.462 & 55.700 & 6.243 \\
\hline 3 & $\begin{array}{c}1.52 \\
2\end{array}$ & 8.013 & 63.713 & $\begin{array}{c}1.52 \\
2\end{array}$ & 8.013 & 63.713 & 5.273 \\
\hline 4 & .871 & 4.582 & 68.295 & & & & \\
\hline 5 & .713 & 3.755 & 72.050 & & & & \\
\hline 6 & .578 & 3.042 & 75.092 & & & & \\
\hline 7 & .526 & 2.768 & 77.860 & & & & \\
\hline 8 & .499 & 2.624 & 80.484 & & & & \\
\hline 9 & .469 & 2.466 & 82.951 & & & & \\
\hline 10 & .453 & 2.386 & 85.337 & & & & \\
\hline 11 & .431 & 2.269 & 87.606 & & & & \\
\hline 12 & .385 & 2.024 & 89.630 & & & & \\
\hline 13 & .349 & 1.838 & 91.468 & & & & \\
\hline 14 & .325 & 1.711 & 93.179 & & & & \\
\hline 15 & .307 & 1.617 & 94.795 & & & & \\
\hline
\end{tabular}


International Journal of Innovation, Creativity and Change. www.ijicc.net

Volume 14, Issue 12, 2020

\begin{tabular}{|c|c|c|c|l|l|l|l|}
\hline 16 & .267 & 1.405 & 96.200 & & & & \\
\hline 17 & .258 & 1.355 & 97.555 & & & & \\
\hline 18 & .243 & 1.280 & 98.835 & & & & \\
\hline 19 & .221 & 1.165 & 100.000 & & & & \\
\hline
\end{tabular}

Extraction Method: Principal Component Analysis.

a. When components are correlated, sums of squared loadings cannot be added to obtain a total variance.

EFA was performed on 71 items which subsequently during the treatment 52 items were deleted and the final number reduces to 19 items. Three factor loading matrix is appended below which clearly shows the loadings with desired values of greater than 0.4 , no double loadings and no negative loadings.

Table 4: Three Factor Loadings Pattern Matrix

\begin{tabular}{|l|l|l|l|}
\hline \multirow{2}{*}{} & Component & \multicolumn{2}{l|}{} \\
\cline { 2 - 4 } & 1 & 2 & 3 \\
\hline TND4 & .932 & & \\
\hline TND5 & .809 & & \\
\hline TND7 & .765 & & \\
\hline TND2 & .761 & & \\
\hline TND6 & .746 & & \\
\hline TND3 & .735 & & \\
\hline TND8 & .732 & & \\
\hline TND11 & .692 & & \\
\hline Appr3 & & .820 & \\
\hline PayNComp5 & & .808 & \\
\hline Appr2 & & .805 & \\
\hline Appr1 & & .794 & .780 \\
\hline Appr4 & & .783 & .749 \\
\hline Appr5 & & .731 & .680 \\
\hline WrkLyfBal2 & & & .679 \\
\hline EmpWlfrErg2 & & & \\
\hline WrkLyfBal3 & & & \\
\hline EmpWlfrErg3 & & & \\
\hline WrkLyfBal4 & & & \\
\hline
\end{tabular}


International Journal of Innovation, Creativity and Change. www.ijicc.net

Volume 14, Issue 12, 2020

Matching parallel to the 3 factor loadings of the items with eigenvalues greater than 1, cumulative variance \%age of above $60 \%$ and items with the higher extractions in communalities were retained for further examination of CFA.

\begin{tabular}{|l|c|c|}
\hline \multicolumn{3}{|c|}{ Table 5: Communalities } \\
\hline PayNComp5 & Initial & Extraction \\
\hline Appr1 & 1.000 & .604 \\
\hline Appr2 & 1.000 & .674 \\
\hline Appr3 & 1.000 & .691 \\
\hline Appr4 & 1.000 & .689 \\
\hline Appr5 & 1.000 & .646 \\
\hline TND2 & 1.000 & .660 \\
\hline TND3 & 1.000 & .662 \\
\hline TND4 & 1.000 & .593 \\
\hline TND5 & 1.000 & .754 \\
\hline TND6 & 1.000 & .673 \\
\hline TND7 & 1.000 & .647 \\
\hline TND8 & 1.000 & .582 \\
\hline TND11 & 1.000 & .591 \\
\hline WrkLyfBal2 & 1.000 & .659 \\
\hline WrkLyfBal3 & 1.000 & .689 \\
\hline WrkLyfBal4 & 1.000 & .642 \\
\hline EmpWlfrErg2 & 1.000 & .602 \\
\hline EmpWlfrErg3 & 1.000 & .550 \\
\hline Extraction Method: Principal Component Analysis. & \\
\hline
\end{tabular}

\section{Phase - VI (Confirmatory Factor Analysis):}

Since, EFA is very useful for the assessment of the extent to which any set of items assess a specific set of scales yet a major weakness of this technique is that it is unable to gauge the goodness-of-fit of the residual and final factor structure (Hinkin, Tracey, \& Enz, 1997) \& (Long, 1983). Confirmatory Factor Analysis is executed using AMOS version 21 based on best fit of 35 items earlier exposed in EFA with 6 factor loading and each path parameters' regression coefficient of every first item is restricted to " 1 ". To obtain the best values of factor loadings few items were deleted with low loadings and the test was re-performed. At very iteration, the model fit was observed as discussed above, along with the validity and correlations between the variables. Finally, the best fit model was obtained with minimum factor loading of 0.71 between the latent variable and observed variables. 
International Journal of Innovation, Creativity and Change. www.ijicc.net

Volume 14, Issue 12, 2020

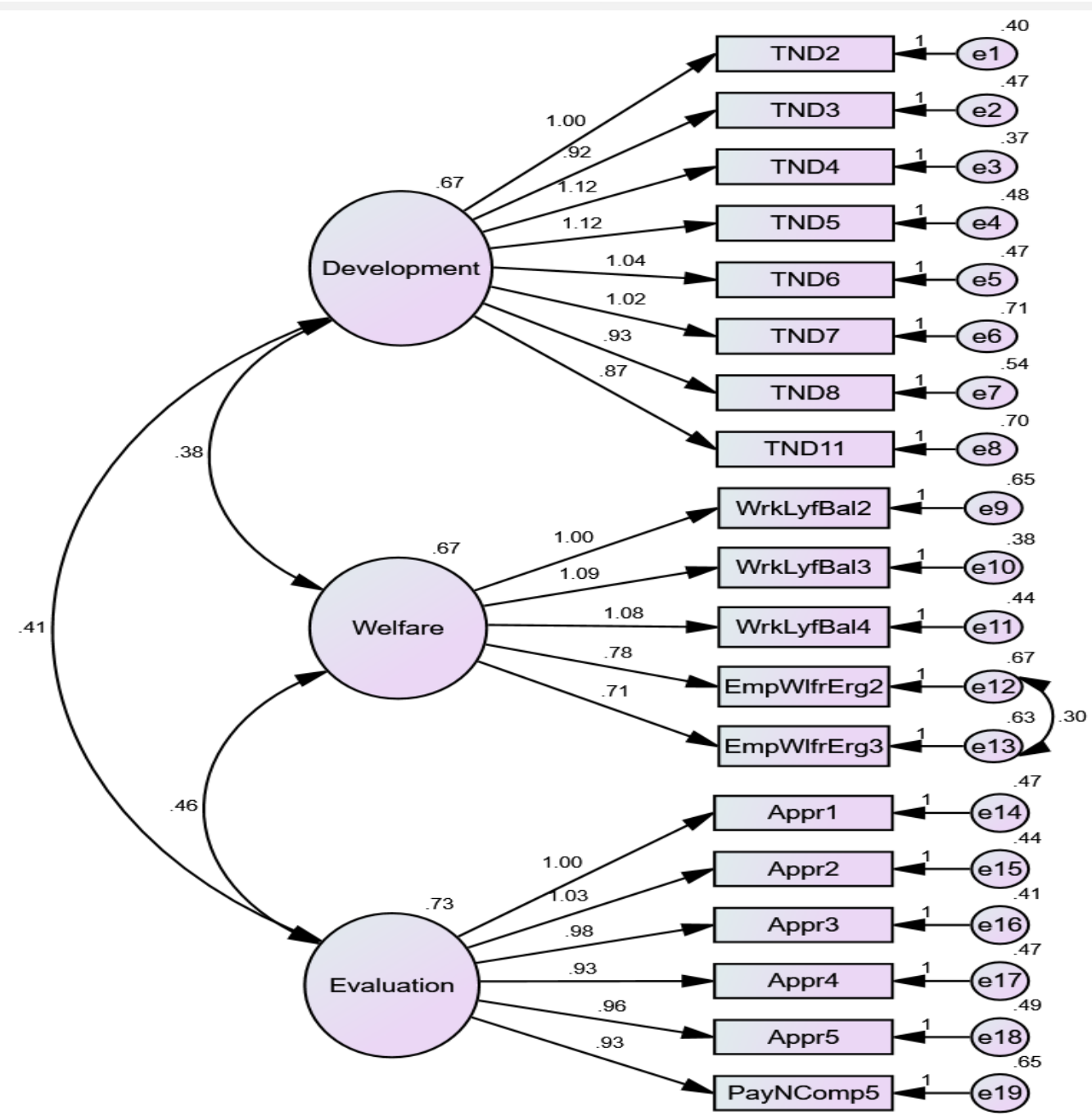

Figure 2: Standardized Factor Loadings: Measurement Model

\section{Validity and Reliability Statistics}

A primary goal of scale development is to create a valid measure of an underlying construct.

\section{Validity}

Average Variance Extracted (AVE) for each construct is calculated to ensure the convergent validity of the scale. The value of AVE greater than 0.5 ensures the significance of the items in the measurement model. For each of the three latent variables the value of AVE is greater than 0.5 hence depicts no convergent validity concerns. For the best fit CR should be less than AVE should be less than MSV. 
Table 6: Validity and Reliability Matrix

\begin{tabular}{|l|c|c|c|c|c|c|c|}
\hline & CR & AVE & MSV & Max R(H) & Development & welfare & Evaluation \\
\hline Development & 0.913 & 0.568 & 0.346 & 0.918 & $\mathbf{0 . 7 5 4}$ & & \\
\hline Welfare & 0.837 & 0.511 & 0.429 & 0.945 & 0.566 & $\mathbf{0 . 7 1 5}$ & \\
\hline Evaluation & 0.895 & 0.586 & 0.429 & 0.963 & 0.588 & 0.655 & $\mathbf{0 . 7 6 6}$ \\
\hline
\end{tabular}

The final set of values in the table above shows that correlation values does not exceed 0.85 hence shows no discriminant validity concerns in the measurement model.

\section{Reliability}

In this study reliability is measured in two different phases. The first one was before running the Factor Analyses and the second was after running the factor analyses.

\section{Pre - Factor Analyses}

Before performing the factor analyses (EFA and CFA), internal reliability was tested through the measures of Cronbach's Alpha as suggested by (Churchill, 1979). The values obtained in the internal reliability of the scale was .972 which was more than the threshold value of .70

\section{Post - Factor Analyses}

Composite reliability (CR) was tested after the factor analyses have been performed. Composite reliability depicts the internal consistency of the latent variables. The table above shows the values quite higher than the threshold value, ensuring the internal consistency of the construct. 
International Journal of Innovation, Creativity and Change. www.ijicc.net

Volume 14, Issue 12, 2020

Table 7: Items Refinement Statistics

\begin{tabular}{|c|c|c|c|l|l|c|}
\hline $\begin{array}{c}\text { Tota } \\
\text { I } \\
\text { Item } \\
\text { S }\end{array}$ & $\begin{array}{c}\text { Items } \\
\text { Delete } \\
\mathbf{d}\end{array}$ & $\begin{array}{c}\text { Remain } \\
\text { ing } \\
\text { Items }\end{array}$ & $\begin{array}{c}\text { Sub- } \\
\text { Dimensi } \\
\text { on }\end{array}$ & \multicolumn{1}{|l|}{ Reason to Delete } & Responsible & Phase \\
\hline 150 & 42 & 108 & 11 & $\begin{array}{l}\text { Wrongly constructed, } \\
\text { Double barreled, } \\
\text { Irrelevant }\end{array}$ & $\begin{array}{l}\text { SME (Subject } \\
\text { Matter Experts) }\end{array}$ & $\begin{array}{c}\text { Phase - II } \\
\text { (A) }\end{array}$ \\
\hline 108 & 37 & 71 & 11 & $\begin{array}{l}\text { Redundant, Irrelevant, } \\
\text { Misfit statements }\end{array}$ & $\begin{array}{l}\text { Scholarly } \\
\text { Students }\end{array}$ & $\begin{array}{c}\text { Phase - II } \\
\text { (B) }\end{array}$ \\
\hline 71 & 2 & 69 & 11 & $\begin{array}{l}\text { Reliability Coefficient } \\
\text { - Cronbach's Alpha }\end{array}$ & $\begin{array}{l}\text { Data Screening } \\
\text { Phase - V } \\
\text { (A) }\end{array}$ \\
\hline 69 & 34 & 35 & 9 & $\begin{array}{l}\text { Poor Factor Loadings } \\
\text { Exploratory } \\
\text { Factor Analysis } \\
\text { (EFA) }\end{array}$ & $\begin{array}{c}\text { Phase - V } \\
\text { (B) }\end{array}$ \\
\hline 35 & 11 & 24 & 7 & $\begin{array}{l}\text { Insignificance of } \\
\text { Model Fit }\end{array}$ & $\begin{array}{l}\text { Confirmatory } \\
\text { Factor Analysis } \\
\text { (CFA) }\end{array}$ & $\begin{array}{c}\text { Phase - VI } \\
\text { (A) }\end{array}$ \\
\hline 24 & 5 & $\mathbf{1 9}$ & $\mathbf{3}$ & $\begin{array}{l}\text { Validity and } \\
\text { Reliability } \\
\text { insignificance }\end{array}$ & $\begin{array}{l}\text { Validity and } \\
\text { Reliability } \\
\text { Analysis }\end{array}$ & $\begin{array}{c}\text { Phase - VI } \\
\text { (B) }\end{array}$ \\
\hline
\end{tabular}

\section{Discussion}

The objective of the study was twofold; first, to gain a deeper understanding of the concept of Employer Engagement and identification of the sub-dimensions with reference to the workbased learning providers, and second objective was to develop a new valid and reliable scale. Since, less studies and literature are found. To accomplish this task we have covered the study in VI distinctive phases, each covering and justifying all the requisite parameters to develop a deeper understanding of the construct and development of the new scale. The results show us that Employer Engagement as per the definitions of the researchers "The active participation of employers in initiatives to promote the employability and labour market participation of the unemployed" (McGurk, 2014) does not exactly fit the concept. It does not only refer to the initiatives taken by the employers to promote the employability rather it goes a step ahead of this. A deep look at the result depicts that no item pertaining to the study was retained related to recruitment and selection. This draws our attention that recruitment and selection, placement and offering jobs does not explain employer engagement and this is their role which they are playing in the society. Further, it is the basic need of the employers to hire fresh and experienced staff to fulfill business needs of the organizations and earn profit. This theme of understanding is re-assured by the definition provided by common wealth "A concept which, 
in addition to providing job opportunities for young people, enlists employers as partners in the process of preparing them for work

Employer engagement is a competitive advantage as far as the rivalry is concerned. In earlier era, Reference to strategic HRM theory: It is proposed that the strength of an employer's engagement may be explained by the organization's human resource (HR) architecture (Lepak and Snell 1999). The context of Lepak is quite close to the results of this study.

We end up with three measurement variables Development; covering items of Training and Development and factor loadings ranging from .87 to 1.12, Welfare; covering items related to Work Life Balance and Employee Welfare and Ergonomics sub-dimensions with factor loadings ranging from .71 to 1.09 , followed with Evaluation that covers the items from Appraisal and Pay \& Compensations sub-dimensions with factor loadings ranging from .93 to 1.03. All these items are highly significant and show a marvelous acceptance level. Explanation of the construct is significantly extended by the above 5 sub-dimensions. A closer look in the results shows that all these sub-dimensions fall under the category of Human Resource Practices that a company adopts and practice.

\section{Development}

Every firm's competitive advantage is continually threatened (D'Aveni, 1994; Ghemawat, 1991; Reed \& DeFillipi, 1990). Firms always take necessary and crucial measures to mitigate the threats associated. As Bamey notes, "Although a firm's resources and capabilities have added value in the past, changes in customer tastes, industry structure, or technology can render them less valuable in the future."

Table 8: Items of 1st Latent Variable

\begin{tabular}{|c|l|c|}
\hline & \multicolumn{1}{|c|}{ Development } & CFA \\
\hline Item \# & \multicolumn{1}{|c|}{ Item Description } & Loading \\
\hline TND2 & $\begin{array}{l}\text { To what extent your organization ensures the existence \& } \\
\text { implementation of a well designed training policy? }\end{array}$ & 1.00 \\
\hline TND3 & $\begin{array}{l}\text { To what extent your organization ensures that productivity of } \\
\text { employees is enhanced through training to achieve organizational } \\
\text { goals? }\end{array}$ & 0.92 \\
\hline TND4 & $\begin{array}{l}\text { To what extent your organization ensures that well planned training } \\
\text { programs are organized throughout the year? }\end{array}$ & 1.12 \\
\hline TND5 & $\begin{array}{l}\text { To what extent your organization ensures that all employees are given } \\
\text { adequate importance for getting nomination in training? }\end{array}$ & 1.12 \\
\hline TND6 & $\begin{array}{l}\text { To what extent your organization ensures that employees in the } \\
\text { organization participate in determining the training they need? }\end{array}$ & 1.04 \\
\hline
\end{tabular}


International Journal of Innovation, Creativity and Change. www.ijicc.net

Volume 14, Issue 12, 2020

\begin{tabular}{|l|l|c|}
\hline TND7 & $\begin{array}{l}\text { To what extent your organization ensures that TNA (Training Need } \\
\text { Analysis) is conducted on annual basis? }\end{array}$ & 1.02 \\
\hline TND8 & $\begin{array}{l}\text { To what extent your organization ensures that the content of the } \\
\text { training programs are always relevant to the changing needs of jobs } \\
\text { and business? }\end{array}$ & 0.93 \\
\hline TND11 & $\begin{array}{l}\text { To what extent your organization ensures To what extent your } \\
\text { organization ensures participation of employees in various seminars } \\
\text { and workshops? }\end{array}$ & 0.87 \\
\hline
\end{tabular}

\section{Welfare}

In this study the domain of welfare is related to Work Life Balance, Employee Welfare related policies in the organizations and Ergonomics. The literature also proposes that an imbalance between work and non-work activities reduce psychological and physical well-being.

Table 9: Items of 2nd Latent Variable

\begin{tabular}{|c|l|c|}
\hline & \multicolumn{1}{|c|}{ Welfare } & CFA \\
\hline Item \# & \multicolumn{1}{|c|}{ Item Description } & Loading \\
\hline WrkLyfBal2 & $\begin{array}{l}\text { To what extent your organization ensures that working hours } \\
\text { are practical and feasible? }\end{array}$ & 1.00 \\
\hline WrkLyfBal3 & $\begin{array}{l}\text { To what extent your organization ensures that initiatives are } \\
\text { taken to help manage work life of its employees? }\end{array}$ & 1.09 \\
\hline WrkLyfBal4 & $\begin{array}{l}\text { To what extent your organization ensures that the work pressure } \\
\text { is evenly distributed among all employees? }\end{array}$ & 1.08 \\
\hline EmpWlfErg2 & $\begin{array}{l}\text { To what extent your organization ensures that proper time and } \\
\text { money is spent on improving safety standards? }\end{array}$ & 0.78 \\
\hline EmpWlfErg3 & $\begin{array}{l}\text { To what extent your organization ensures that unsafe working } \\
\text { conditions are identified and improved promptly / immediately? }\end{array}$ & 0.71 \\
\hline
\end{tabular}

\section{Evaluation}

Appraising and compensating the employees has been addressed enormously in different researches. Studies depict the importance and relevance of these HR practices in the organizations. Practically, it is experienced that organizations do acquire the practice and policy of appraising its employees but exercise many fool practices. 
International Journal of Innovation, Creativity and Change. www.ijicc.net

Volume 14, Issue 12, 2020

Table 10: Items of 3rd Latent Variable

\begin{tabular}{|l|l|c|}
\hline \multicolumn{1}{|c|}{ Item \# } & \multicolumn{1}{|c|}{ Evaluation } & CFA \\
\hline Appr1 & $\begin{array}{l}\text { Ttem Description } \\
\text { implementation of fair and objective performance appraisal? }\end{array}$ & Loading \\
\hline Appr2 & $\begin{array}{l}\text { To what extent your organization ensures that efforts put in by } \\
\text { employees are fairly reflected in their annual appraisal? }\end{array}$ & 1.00 \\
\hline Appr3 & $\begin{array}{l}\text { To what extent your organization ensures that views \& } \\
\text { perspectives of employees are considered while preparing the } \\
\text { appraisal? }\end{array}$ & 0.98 \\
\hline Appr4 & $\begin{array}{l}\text { To what extent your organization ensures that accurate } \\
\text { information is used while doing an appraisal? }\end{array}$ & 0.93 \\
\hline Appr5 & $\begin{array}{l}\text { To what extent your organization ensures that employees are } \\
\text { treated with dignity and respect throughout the appraisal } \\
\text { process? }\end{array}$ & 0.96 \\
\hline PayNComp5 & $\begin{array}{l}\text { To what extent your organization ensures that the rewards and } \\
\text { incentives are fairly distributed among all employees? }\end{array}$ & 0.93 \\
\hline
\end{tabular}

Significant loadings of the items show that the practice of appraisal is critical to the employees' satisfaction and an important tool to increase the organizational performance by increasing the commitment of the employees. The degree of engagement increases when the organizations support the staff for meeting their basic needs and prosperity accordingly as described by (Maslow, 1954).

\section{Conclusion}

An effort is made through this study to explore the possible understanding of the Employer Engagement as a new construct specifically in context of the work-based learning providers. Commencing with 11 sub-dimensions and finally approaching to 3. So, this study concludes that employer engagement basically encompass the HR practices with exclusive concentration on Development of the work force, intelligent and efficient management of the knowledge and skill set and preparing them proactively for the rapid changes to maintain the competitive advantage and cope the rivalry; enhance the working environment of the work place and support and assist the employees with Welfare policies and pay and compensation including rewards, incentives and other benefits to increase their commitment and loyalty with their organization as well as with their profession.

\section{Limitations and Future Recommendations}

Every research has limitations to the scope of work it carried in, so is this study. The time constraint was an issue. This study is carried out using convenience sampling, which could be 
some other probability sampling. Since, the scale development is a critical task to carry, therefore, the non-probability sampling might have not covered the purpose. For any future study, it is extended that any probability sampling technique should be used.

Measures are adapted from existing studies and data is collected through surveys of the questionnaire. It is extended that interviews should also be included along with the practice performed in this study. This ways the deeper understanding of the respondents can be achieved and accumulated.

\section{Author Contribution}

All authors equally contributed to conception and design, acquisition of data at every phase, analysis and interpreting of results. They also drafted the manuscript according to their research skills. All authors approved the final manuscript to be published and agreement to be accountable for all the phases of study regarding accuracy or integrity of work. 
International Journal of Innovation, Creativity and Change. www.ijicc.net

Volume 14, Issue 12, 2020

\section{REFERENCES}

(QAA), Q. A. (2005). Learning from reviews of foundation degrees in England. Gloucester, UK: QAA.

Alexandra, S.-B., \& Frank J., F. (2015). Scale Development: The Encyclopedia of Clinical Psychology.

Amaram, D. I. (2007). Cultural diversity: Implications for workplace management.

Armstrong, M. (2006). A Hand book of HUMAN RESOURCE MANAGEMENT PRACTICES. Philedelphia USA.

Aswathappa, K. (2000). Human resource and Personnel Management, New Delhi: p-189. Tata Mcgraw-Hil.

Ayadurai, D. (1996). Industrial Relations in Malaysia: Law and Practice 2. Malayan Law Journal.

Banker, R., Lee, S., Potter, G., \& Srinivasan, D. (2001). An empirical analysis of continuing improvements following the implementation of a performance based compensation plan. Journal of Accounting and Economics.

Barber, \& Linda. (2004). CSR for Employees: "Proof of Employer Engagement". INSTITUTE FOR EMPLOYMENT STUDIES.

Baron, J. N., \& Hannan, M. T. (2002). Organizational blueprints for success in high-tech start-ups: Lessons from the Stanford project on emerging companies. California Management Review.

Barrick, M. R., Thurgood, G. R., Smith, T. A., \& Courtright, S. H. (2015). COLLECTIVE ORGANIZATIONAL ENGAGEMENT: LINKING MOTIVATIONAL ANTECEDENTS, STRATEGIC IMPLEMENTATION, AND FIRM PERFORMANCE. Academy of Management Journal.

Barringer, B. R., Jones, F. F., \& Neubaum, D. O. (2005). A quantitative content analysis of the characteristics of rapid-growth firms and their founders. Journal of Business Venturing.

Bassett-Jones, N. (2005). "The paradox of diversity management" .

Bayissa, L., Asfaw, A. M., \& Argaw, M. D. (2015). The Impact of Training and Development on Employee Performance and Effectiveness:

Bean, R. (1994). Comparative Industrial Relations: An Introduction To Cross-National Perspectives. 2nd Edition. London: Routledge.

Bell, M. (2006). Managing diversity in organizations. Mason, OH: Thomsen.

Bemmels, B., \& Resyef, Y. (1991). The Roles of Supervisors, Employees and Stewards in Grievance Initiation. Industrial \& Labor Relations Review. 
International Journal of Innovation, Creativity and Change. www.ijicc.net Volume 14, Issue 12, 2020

Berkel, R. v., Ingold, J., McGurk, P., Bredgaard, T., \& Boselie, P. (2015). Employer engagement: connecting social policies and human resource policies for vulnerable labour market groups.

Beutell, N., \& Greenhaus, J. (1985). Sources of conflict between work and family roles. Academy of Management Review.

Boon, Paauwe, C., Boselie, J., \& Hartog, D. (2009). Institutional pressures and HRM: developing institutional fit, Personnel Review.

Bowen, H. R. (1953). Social Responsibilities of the Businessman. . New York: Harper.

Boxall, P., \& Purcell, P. (2011).

Brammer, S., Jackson, G., \& Dirk, M. (2012). "Corporate Social Responsibility and Institutional theory: new perspective on private governance".

Buitendach, J. H., \& Witte, H. D. (2005). Job insecurity, extrinsic and intrinsic job satisfaction and affective organisational commitment of maintenance workers in a parastatal. South African Journal Business Management.

Bustillo, R. M., \& Pedraza, P. (2005). Measuring job insecurity in the Wage Indicator.

Cardon, M. S., \& Stevens, C. E. (2004). Managing human resources in small organizations: What do we know? Human Resource Management Review.

Carrell, M., Elbert, N., \& Hatfield, R. (2000). Human Resource Management: Strategies for managing a diverse and global workforce. Orlando: Dryden.

Carroll, A. B. (1979). “A Three-Dimensional Conceptual Model of Corporate Performance.” . Academy of Management Review.

Child, J. (1972). Organizational structure, environment and performance: The role of strategic choice. Sociology.

Chiumento. (2004). Get Engaged. In Armstrong, M.(2006), A Handbook of Human Resource Management Practice. 10th Edition.

Cho, S., Woods, R. H., Jang, S., \& Erdem, M. (2005). Measuring the impact of human resource management practices on hospitality firms' Performances. International Journal of Hospitality Management.

Churchill, G. (1979). A paradigm for developing better measures of marketing constructs. Journal of Marketing Research, 16, 64-73.

Clark, F. (1988). The role of the steward in shaping union member attitudes toward the grievance procedure. . Labor Studies Journal.

Collins, J. C., \& D., C. K. (2003). Strategic human resource practices, top management commitment, team social networks and firm performance: the role of human resource practices in creating organizational competitive advantage. Academy of Management Journal. 
International Journal of Innovation, Creativity and Change. www.ijicc.net Volume 14, Issue 12, 2020

Collins, K., Greenhaus, J., \& Shaw, J. (2003). The relation between work-family balance and quality of life. Journal of Vocational Behavior.

Common Wealth. (2013). Strategic Employer Engagement - Building Dynamic Relationships with Employers in Teen and Young Adult Employment Programs: A Workforce Development Practitioner's Guide. Common Wealth Corporation.

Connerley, M. L., \& Pedersen, P. B. (2005). Leadership in a diverse and multicultural environment. Thousand Oaks, CA: Sage.

Cox, T. H. (2000). Creating the multicultural organization: A strategy for capturing the power of diversity. . San Francisco: Jossey-Bass.

Cullen, J., \& Farrelly, M. (2005). Best Practice HR in Ireland. Cork: Oak Tree Press.

CWC. (n.d.). (Common Wealth Corporation - Strategic Employer Engagement ). Retrieved from www.commcorp.org.

Cyert, M. R. (1963). A behavioral theory of the firm. Upper Saddle River, NJ: Prentice Hall.

D’Cruz, M. (1999). A Practical Guide to Grievance Procedure, Misconduct and Domestic Inquiry. Kuala Lampur: Leeds Publications.

Dass, P., \& Parker, B. (1996). 'Diversity: A strategic issue', in Managing Diversity: Human Resource Strategies for Transforming the Workplace.

Doyle, M. (1997). Management development, in Beardwell, I. and Holden, L. eds Human Resource Management: A Contemporary Perspective.

Duxbury, L. (2004). Dealing with work-life issues in the workplace: Standing still is not an option. The 2004 Don Wood Lecture in Industrial Relations.

Farrell, A. M. (2010). Insufficient discriminant validity: A comment on Bove, Pervan, Beatty, and Shiu.

Fey, C. E., Bjorkman, I., \& Pavlovskaya, A. (2000). The impact of human resource management practices on firm performance in Russia. International Journal of Human Resource Management.

Frank, J., Landy, Sheldon, Zedeck, \& Cleveland, J. (1983). Performance measurement and theory. Business \& Economics.

Gorush, R. (1983). Factor Analysis. 2nd ed. . Hillsdale, NJ: Lawrence Erlbaum and Associates.

Goyal, P. (1995). Labour Welfare and Job Satisfaction.

Harter, J. K., Schmidt, F. L., \& Hayes, T. L. (2002). Business unit-level relationship between employee satisfaction employee engagement, and business outcomes. Journal of Applied Psychology. 
International Journal of Innovation, Creativity and Change. www.ijicc.net Volume 14, Issue 12, 2020

Hayley, G., FORTIN, M., \& READ, D. (2016). JUSTICE JUDGMENTS: INDIVIDUAL SELF-INSIGHT AND BETWEEN- AND WITHIN-PERSON CONSISTENCY.

Hinkin, T. (1995). A review of scale development practices in the study of organizations. Journal of Management, 21, 967-988.

Hinkin, T. R., Tracey, J. B., \& Enz, C. A. (1997). Scale Construction: Developing Reliable and Valid Measurement \& Instruments. Retrieved from http://scholarship.sha.cornell.edu/articles/613

Hook, C., Rollinson, D., Foot, M., \& Handley, J. (1996). Supervisor and Management Styles in Handling Discipline And Grievance (part one): Comparing Styles in Handling Discipline And Grievance. Personnel Review.

Hughes, Macleod, D., \& Maria. (2005). What we know about working with employers: a synthesis of LSDA work on employer engagement.

Huselid, M. A. (1995). The impact of human resource management practices on turnover, productivity and corporate financial performance. Academy of Management Journal.

István, J. (2010). Selection methods used in recruiting sales team members. .

Jayne, M. E., \& Dipboye, R. L. (2004). "Leveraging diversity to improve business performance: Research findings and recommendations for organizations".

Jerez-Gómez, P., Céspedes-Lorente, J., \& Valle-Cabrera, R. (2005). ORGANIZATIONAL LEARNING AND COMPENSATION STRATEGIES: EVIDENCE FROM THE SPANISH CHEMICAL INDUSTRY. Human Resource Management.

John, W. (2014). Employer Engagement Editorial.

Joseph, F. H., William, J., Black, C., Babin, B. J., \& Anderson, R. E. (210). Multivariate Data Analysis.

Kahn, R., Wolfe, D., Quinn, R., Snoek, J., \& Rosenthal, R. (1964). Organizational stress: studies in role conflict and ambiguity. Wiley.

Katou, A. A., \& Budhwar, P. S. (2006). Human resource management systems and organizational performance: A test of a mediating model in the Greek manufacturing context.

Kenneth, T., MacDermid, J. C., Amick, B. C., \& Beaton, D. E. (2011). The 11-Item Workplace Organizational Policies and Practices Questionnaire (OPP-

11):Examination of Its Construct Validity, Factor Structure, and Predictive Validity in Injured Workers With Upper-Limb Disorders.

Kinicki, A., Prussia, G., Bin, W., \& McKee-Ryan, F. (2004). Covariance Structure Analysis of Employees- Response to Performance Feedback. Journal of Applied Psychology. 
International Journal of Innovation, Creativity and Change. www.ijicc.net Volume 14, Issue 12, 2020

Kolgiri, S., Hiremath, R., \& Bansode, S. (2016). Literature Review on Ergonomics Risk Aspects Association to the Power Loom Industry. Journal of Mechanical and Civil Engineering.

Kulkarni, P. P. (2013). A LITERATURE REVIEW ON TRAINING \& DEVELOPMENT AND QUALITY OF WORK LIFE. Journal of Arts, Science \& Commerce.

Lee Anna, C., \& Watson, D. (1995). Construction Validity: Basic Issues in Objective Scale Development.

Long, J. (1983). Confirmatory factor analysis. . Beverly Hills: Sage Publications.

Lopez, J. F. (1968). Evaluating employee performance. . Public Personnel Association, Chicago.

Marius, D. (2006). "Welfare Effects on Union Bargaining Centralisation on a Two Sector Economy".

Marks, S., \& MacDermid, S. (1996). Multiple roles and the self: A theory of role balance. . Journal of Marriage and the Family.

McGurk, P. (2014). Employer engagement: a human resource management perspective.

McWilliams, A., \& Seigel, D. S. (2010). "Creating and Capturing Value: Strategic Corporate Social Responsibility, Resource-based theory and sustainable competitive advantage".

Meyer, D. (1994). The Political Effects of Grievance Handling by Stewards In a Local Union. Journal of Labor Research.

Munyon, P. T., Summers Ferris, K. J., \& Gerald, R. (2011). Team staffing modes in organizations Strategic considerations on individual and cluster hiring approaches.

Ngo, H., Turban, D., Lau, C., \& Lui, S. (1998). Human resource practices and firm performance of multinational corporations: influences of country origin. International Journal of Human Resource Management.

Noe, R., Hollenbeck, J., Gerhart, B., \& Wright, P. (2003). . Human Resource Management. New York: Mc Graw Hill.

Northumbria. (2011). Staff equality and diversity perception survey.

O’Donoghue, K. (2014). Why Does Employer Engagement Matters - A tool kit for managing employer activies in schools and colleges.

Ongori, H., \& Agolla, J. E. (2007). Critical review of literature on workforce diversity.

Palaiologos, A., Papazekos, P., \& Panayotopoulou, L. (2011). Organizational justice and employee satisfaction in performance appraisal. Journal of European Industrial Training.

Parry, E., \& H, W. (2009). Influencing the Adoption of Online Recruitment". 
International Journal of Innovation, Creativity and Change. www.ijicc.net Volume 14, Issue 12, 2020

Pfeffer, J. (1998). Seven practices of successful organizations. California Management Review.

Quinn, D. (2014). An evaluation of the recruitment and selection process employed by "Manufacturing Company X" and assessing whether a more advanced process or method of recruitment and selection may reduce staff turnover.

Raymond, J. S. (2007). Human Resource Management. Business \& Economics.

Rich, B. L. (2010). job engagement: Antecedents and effects on job performance. Academy of Management Journal.

Roberson, L., Kulik, C. T., \& Pepper, M. B. (2003). Using needs assessment to resolve controversies in diversity training design. Group and Organization Management.

Roger Bennett, S. K. (2009). Employer engagement practices of UK business schools and departments: an empirical investigation.

Rummel, R. (1970). Applied factor analysis. Evanston, IL: Northwestern University Press.

Salamon, M. (2000). Industrial Relations: Theory And Practice. 4th Edition. Great Britain: Prentice Hall.

Sang, C. (2005). Relationship between human resource management practices and perception of organizational Taiwan performance, roles of management style, social capital, and culture: Comparison between manufacturing firms in Cambodia and Taiwan.

Schendel, D. E. (1979). Strategic management: A new view of business policy and planning.

Schmitt, N., \& Klimoski, R. (1991). Research methods in human resources management.

Schwab, D. (1980). Construct validity in organization behavior. In B.M. Staw \& L.L. Cummings. Research in organizational behavior.

Selvarajan, T., \& Cloninger, P. (2009). The Influence of Job Performance Outcomes on Ethical Assessments. Personnel Review.

Shockley, K. M., Ureksoy, H., Rodopman, O. B., Poteat, L. F., \& Dullaghan, T. R. (2016). Development of anew scale to measure subjective career success: A Mixed methods Study. Journal of Organizational Behavior.

Singla, A. K., \& Goyal, C. (2015). EMPLOYEES WELFARE MEASURES IN SMEs: A STUDY OF DOABA STEEL ROLLING MILLS. International Journal In Applied Studies And Production Management.

Sirmon, D. G. (2007). Managing firm resources in dynamic environments to create value: Looking inside the black box. Academy of Management Review.

Sorrel, B. (2010). ANR Program Evaluation: Likert Scale Examples for Surveys. Iowa State University Extension.

Stewart, T. (1997). Intellectual capital New York: Doubleday-Country. 
International Journal of Innovation, Creativity and Change. www.ijicc.net Volume 14, Issue 12, 2020

Stockdale, M. S., \& Cao, F. (2004). Looking back and heading forward: Major themes of the psychology and management of workplace diversity. In M. S. Stockdale \& S. Crosby (Eds.), The psychology and management of workplace diversity. . Malden MA: Blackwell.

Syed, Z. J. (2012 ). Universalistic perspective of HRM and organizational performance: meta analytical study.

Tan, C. L., \& Nasurdin, A. M. (2011). Human Resource Management Practices and Organizational Innovation: Assessing the Mediating Role of Knowledge Management Effectiveness. Electronic Journal of Knowledge Management, Volume 9 Issue 2 (pp155-167),

Te-Hsin, P., \& Kleiner, B. (2001). New developments concerning the occupational safety and health act. . Journal of Managerial Law. .

Tomina Gabriela, S., ABRUDAN, M.-M., GIURGIU, A., MESTER, L. E., \& BUGNAR, N. (2014). MEASURING CORPORATE SOCIAL RESPONSIBILITY PRACTICES OF MICRO AND SMALL ENTERPRISES - PILOT STUDY.

Uen, J., \& Chien, S. (2004). Compensation structure, perceived equity and individual performance of R\&D professionals. Journal of American Academy of Business.

Vyas, A. M. (2011). Human resource recruitment in India: Critical role of online recruitment system.

Warren, T. (2004). Working part-time: Achieving a successful work-life balance? The British Journal of Sociology.

Windsor, D. (2001). "The future of corporate social responsibility". . International Journal of Organizational Analysis.

Wood, R., \& Marshall, V. (2008). Accuracy and Effectiveness in Appraisal Outcomes: The Influence of Self-Efficacy Personal Factors and Organisational Variables. Human Resource Management Journal.

Wright, P. M., Gardner, T. M., Moynihan, L. M., \& Allen, M. R. (2005). The relationship between HR Practices and firm performance: Examining causal order. Personnel Psychology.

Yung-Tai, T., \& Chang, C.-H. (2010). Impact of role ambiguity and role conflict on employee Creativity.

Zheng, C. (2009). Keeping Talents for advancing service firms in Asia.

Zhu, Y. (2004). Responding to the challenges of globalization: human resource development in Japan,. Journal of World Business.

Zulkiflee, B. D., Yahya, K. K., Faizal, M., \& Noor, W. S. (2011). THE INFLUENCE OF HEADS OF DEPARTMENT PERSONALITIES ON THE SELECTION OF GRIEVANCE HANDLING STYLES. 
International Journal of Innovation, Creativity and Change. www.ijicc.net Volume 14, Issue 12, 2020 